\title{
POLICY SHIFT TO REDUCE UNEMPLOYMENT OF VOCATIONAL SECONDARY SCHOOL GRADUATES IN INDONESIA (A NATIONAL STUDY)
}

\author{
Eric Ohara $^{1}$, Slamet Prawiro Harto ${ }^{2}$, and Rita Fransina Maruanaya ${ }^{3}$ \\ ${ }^{1}$ Universitas Pembangunan National, Yogyakarta, Indonesia; ${ }^{2}$ Universitas Negeri Yogyakarta, Yogyakarta, Indonesia; \\ ${ }^{3}$ Institute of Vocational Education and Vocational Didactics, TU Dresden, Germany \\ Email: ericohara@upnyk.ac.id; slametph@uny.ac.id
}

\begin{abstract}
One of the enduring issues and problems in Indonesia is the link and match between vocational secondary schools and the world of work in terms of quantity, quality, location, and time. This research focuses on the first issue i.e. quantity of vocational secondary school graduates in terms of supply and demand. The objective of this research was to explore the proportion of general secondary and vocational secondary school students, to find out the unemployment rate of both school types, and to identify policy alternatives to reduce the unemployment rate of vocational secondary school graduates. To achieve the objective, a quantitative descriptive research method was adopted. The research found that the national average proportion of students from general secondary schools and vocational secondary schools was $62.92 \%: 37.08 \%$ in 2016 and $63.39 \%: 36.61 \%$ in 2019 . The national average unemployment rate of both school graduates was $8.72 \%$ and $11.11 \% \%$ respectively in 2016 , and $7.92 \%$ and $10.42 \%$ respectively in 2019. Thus, the unemployment rate of vocational secondary school graduates was higher than those of general secondary school graduates. In Java Island, however, where the population is about $40 \%$ of the Indonesian total population, the percentage of vocational secondary students increases significantly from 44.34\%:55.66\% in 2016 to 39.91\%:60.09\% in 2019. For this reason, a new policy is needed to reduce the unemployment rate of vocational secondary school graduates in the form of a moratorium for vocational secondary school expansion, particularly in Java Island. If for some reason, there is a need to build new vocational secondary schools in a certain area, it must be based on demand-driven guided by labor market signals. More comprehensively, a policy shift is required to reduce the unemployment of graduates from secondary vocational schools.
\end{abstract}

Keywords: proportion of general and vocational school students, policy shift, unemployment rate

\section{INTRODUCTION}

The enduring issues and problems of vocational education in Indonesia are link and match between vocational education and the world of work in terms of quantity (how many graduates are needed by the world of work), quality (what competencies and capabilities required by the world of work, location (where vocational schools should be offered and what types), and time (when graduates are needed by the workplace). This research focuses only on the first issue i.e. the number of vocational school graduates required by the world of work in terms of supply and demand of labor, and the last three issues will be researched later.

The Indonesian Ministry of Education and Culture (MOEC) embarked major policy decision on the proportion of general secondary school and vocational secondary school students from 70\%:30\% in 2007 to be reversed to $30 \%: 70 \%$ by 2015 , respectively, with the assumption that manpower demands of Indonesian growing economy require more middle workers graduating from secondary vocational schools than from general secondary schools. Consequently, the Indonesian Government had to build more vocational secondary schools than general 
secondary schools, with the expectation that link and match between vocational education and the world of work will be strengthened, and graduates from vocational secondary schools will be absorbed by the world of work. Thus, the supply of labor from vocational schools was supposed to be aligned with the demand for labor from the world of work in terms of quantity. With this policy decision, it was expected that there would be an efficient and smooth transition from school to work. Vocational schools are therefore supposed to be able to contribute to Indonesian growing economy development with the principles of economic (spending less), efficiency (spending well), and effectiveness (spending wisely).

This policy decision poses three questions: (1) what is the proportion of general and vocational secondary school students 2016-2019?; (2) what is the average unemployment rate of general and vocational secondary school graduates or whether graduates from secondary vocational schools are mostly absorbed by the workplaces i.e. employed or unemployed since the policy of expanding secondary vocational schools was only based on assumption?; and (3) what policy shift is required to reduce unemployment rate of graduates from vocational secondary schools? Thus, the objectives of this research were three folds, to explore proportion of general and vocational secondary school students, to find out the unemployment rate of both school types, and to explore policy shifts to reduce unemployment rate of graduates from vocational secondary schools.

Efforts to develop vocational education based on demand-driven by the world of work in terms of quantity, quality, location, and time have been designed, structured, executed, and intensified since 1993 by strengthening link and match between vocational education and the world of work to contribute to a smooth transition of vocational secondary school graduates from school to work. Link and match is a policy decision, it is not a program implementing the policy. The link means having strong collaboration between vocational education and the world of work and match means having accurate requirements that stem from the world of work in terms of quantity, quality, location, and time [1]. The policy decision of link and match was introduced by MOEC in 1993, drawn by researchers. It is presented in Figure 1 and Figure 2.

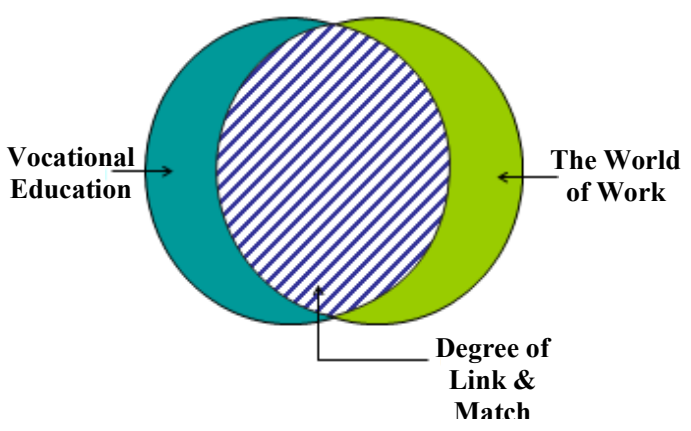

Figure 1. The Degree of Link and Match between Vocational Education and the World of Work

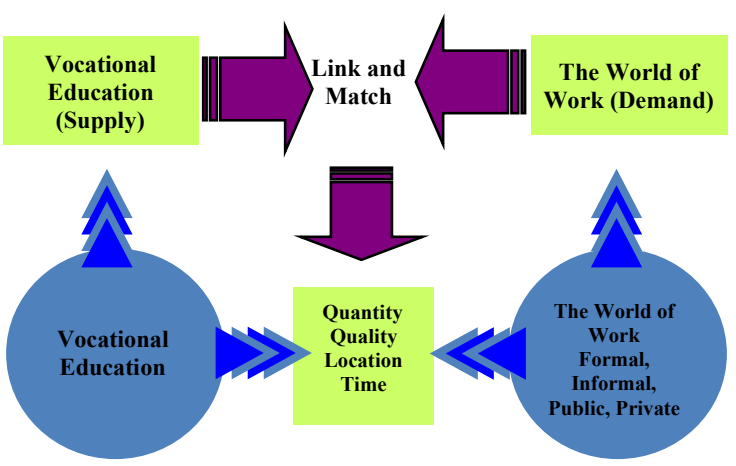

Figure 2. Link and Match between Vocational Education and the World of Work in Terms of Quantity, Quality, Location, and Time

The policy decision of link and match was then legalized by formal collaborated joint Decree Number 0217/U/1994 between the Ministry of Education and Culture and Chamber of Commerce and Industry. This joint Decree was then used as a basis for 
forming the National Task Force in 1995, charged with developing a white paper on vocational education and training. The white paper was then produced in 1997 by the National Task Force, called Skills toward 2020. The essential content of Skills toward 2020 was a change of policy dimensions in vocational education and training (Table 1) [1].

Table 1. Skills toward 2020 (Key Policy Dimensions in Vocational Education and Training in Indonesia)

\begin{tabular}{|c|c|}
\hline The Past & The Future \\
\hline $\begin{array}{l}\text { - A Supply-driven } \\
\text { system based on a } \\
\text { large social demand } \\
\text { - A school-based } \\
\text { system delivering } \\
\text { diploma upon } \\
\text { examination } \\
\text { - A school-based } \\
\text { system with minimum } \\
\text { flexibility in delivery } \\
\text { - No official } \\
\text { recognition of prior } \\
\text { learning } \\
\text { - A school-based } \\
\text { system with a study } \\
\text { program orientation } \\
\text { - Education and } \\
\text { training focused on } \\
\text { the formal sector. } \\
\text { - The separation } \\
\text { between education } \\
\text { and training } \\
\text { - The centralized } \\
\text { system of } \\
\text { management } \\
\text { Institutions/organizati } \\
\text { ons fully supported } \\
\text { and run by the central } \\
\text { government }\end{array}$ & $\begin{array}{l}\text { - A demand-driven } \\
\text { system guided by } \\
\text { labor market signals } \\
\text { - An education and } \\
\text { training system } \\
\text { delivering } \\
\text { competencies in } \\
\text { accord with nationally } \\
\text { recognized standards } \\
\text { - An education and } \\
\text { training system with } \\
\text { multiple entry/exit } \\
\text { points and flexible } \\
\text { delivery } \\
\text { - A System which } \\
\text { explicitly recognizes } \\
\text { skill and competencies } \\
\text { wherever and however } \\
\text { they are obtained } \\
\text { profession and trades } \\
\text { - An education and } \\
\text { training system } \\
\text { oriented towards } \\
\text { officially recognized } \\
\text { professions and trades } \\
\text { - Education and training } \\
\text { both for the normal } \\
\text { and informal sectors } \\
\text { - Full integration of } \\
\text { education and training } \\
\text { from a cognitive } \\
\text { science perspective } \\
\text { - Decentralized system } \\
\text { management } \\
\text { - Self-supporting and } \\
\text { self-managing } \\
\text { institutions or } \\
\text { organizations with } \\
\text { partial support from } \\
\text { the central government }\end{array}$ \\
\hline
\end{tabular}

Commenting briefly on Table 1 , the MOEC envision the following. In the future, vocational secondary schools should be driven by labor market demands, delivering competencies in accord with nationally recognized standards, multiple entry/exit points, and flexible delivery, recognizing prior learning/experience, oriented towards officially recognized professions and trades, equipped to be productive in both formal and informal sectors, decentralized management, and self-managing schools with partial support from central government. Motivated by global requirements and technological development, vocational secondary schools must teach "state of the art" in science and technology as well as global agreement standards.

Based on Skills toward 2020, the Ministry of Education and Culture enacted Decree Number 323/U/1997 on Dual System of Vocational Secondary Schools. Vocational secondary schools are supposed to have partnered with companies. In a dual system, vocational schools and companies working in partnership to develop a legal basis for education in schools and training in companies, to develop competencies required by the companies, to develop curriculum, learning strategies in schools and training strategies in companies, personnel, management, financing, evaluation, and certification. From 1998 to 2009, there was no significant progress in vocational education reform due to combined two main factors i.e. economic slump/crisis and transition from a centralized to a decentralized system of education in Indonesia. In January 2010, however, the Ministry of Education and Culture (MOEC) and Ministry of Manpower and Transmigration (MOMT) of Indonesia collaborated to initiate harmonization/ synchronization of education and the world 
of work, resulting in the Framework for Synchronization of Education and the World of Work [2]. Up until 2014, the Framework was not well implemented due to a lack of legal aspect support and a lack of coordination with the world of work. In essence, the Framework did not work. In 2015, however, the Indonesian President visited Germany with particular attention to the dual system of vocational education and training. After back from Germany, the President enacted President Instruction Number 9 Year 2016 on Revitalization of Vocational Education to Improve Quality and Human Resource Competitiveness [3] followed by implementation strategy guidelines to implement the President Instruction. To some extent, producing President Instruction was the easy part, but the hard part in Indonesia was executing the President Instruction that, in effect, would produce the necessary change.

Readings on link and match (collaboration) between vocational education and the world of work are numerous, some of them are as follows. The projection of the workforce, employed and unemployed, by sectoral and occupational membership, may then be used as a set of requirements or goals for manpower development policies and program development and for setting education/training targets (David Russel, in Slamet Prawiro Harto) [4]. Thus, the supply of labor from education and training institutions must link and match the needs of the industry quantitatively and qualitatively. Education planning must consider the supplydemand of the workforce. Supply must link and match with demands required by the world of work. Perhaps, the leading concept of collaboration between vocational education and the world of work is from Germany, known as "Vocational Training in the Dual System" or "dual system" for short.
Simply summarized, in the dual system, the number of students going to be trained in the company is based on the capacity of the company to accommodate students. In the dual system, students spend roughly onethird time in vocational school and two-third time in the company. Thus, in the dual system, company experiential-based training is complementary with school-based relatedtheory learning. In vocational school, students learn general education and the related theory of work, while in the company, students learn real jobs. The term dual system is sometimes used synonymously with the term experiential education. Experiential education refers to planned education experiences designed to enable learners to acquire attitudes, skills, and knowledge for work and other life roles by participating in work settings. Experiential education may include experience-based career education, cooperative education, action learning, apprenticeship, dual system, clinical experiences, supervised external study, field experience, educational practices, work experience education, work-study, external degree programs, internship, and others (Migual, Richard J in Slamet Prawiro Harto) [5]. Therefore, readjustment of vocational education is required to be in line with economic development and exponential changes of technologies i.e. construction, manufacture, transportation, communication, energy, bio, and material. Obviously, the readjustment of vocational education to the needs of workplaces in the quantitative dimension is the focus of this study.

\section{METHOD}

To answer the research questions, quantitative descriptive research method was adopted to collect, tabulate, and sort quantitative data. Secondary data was utilized 
due to its appropriateness to answer the research problems. Two types of data were collected, namely: (1) the proportion of general secondary students and vocational secondary students, collected from 34 provinces plus several Indonesian schools implemented in several countries. The data was validated with nationally aggregated data collected from the Ministry of Education and Culture; and (2) unemployment rate by level of education, particularly graduates from general secondary schools and vocational secondary schools was collected from the Indonesian Bureau of Statistics Center and 34 Bureaus of Statistic Center at the provincial level. Specifically, in Java Island, both data was split due to the dominant number of secondary vocational schools and the majority of the Indonesian population lives there. Because Java Island consists of six provinces, namely DKI Jakarta (Special Territory as the Capital City of Indonesia), Banten, Jawa Barat, Jawa Tengah, Daerah Istimewa Yogyakarta, Jawa Tengah, and Jawa Timur, therefore, the two types of data were collected from those six provinces and several Indonesian schools abroad. Descriptive data analysis was utilized to find out the proportion of general secondary and vocational secondary students and the unemployment rate of both school types.

\section{RESULTS AND DISCUSSION}

The policy decision to expand vocational secondary schools to accommodate more students resulted as follows. It can be seen from Table 3 that nationally and aggregately from 2016-2019, the average proportion of students from general secondary schools and vocational secondary schools was roughly flat i.e. 62.92\%:37.08\% in 2016 and 63.39\%:36.61\% in 2019. However, the average unemployment from secondary vocational schools was higher than those of general secondary school graduates (Table 4). More specifically in Java Island, the percentage of vocational secondary students increase significantly from $44.34 \%: 55.66 \%$ in 2016 to 39.91\%:60.09\% in 2019 (Table 5). Briefly elaborated, although the average proportion of students from general secondary schools and vocational secondary schools was roughly flat nationally from 2016-2019, in Java Island, the average proportion was dominated by students from vocational secondary schools in all six provinces. From Table 3 (nationally) and specifically from Table 5 (Java Island), it is clear that the percentage of vocational secondary school students was higher than those of general secondary school students. However, the average unemployment rate of graduates from vocational secondary schools was much higher than those of general secondary school graduates, respectively (Table 4). Specific to six provinces in Java Island (Table 6), the unemployment rate of vocational secondary school graduates was all higher than those of their counterparts from general secondary school graduates. The data in Table 4 and Table 6 also indicate that the world of work prefers to employ graduates from general secondary schools than graduates from secondary vocational schools. It is inefficient since vocational secondary schools are purposely designed to prepare students for gainful employment and the costs of running vocational secondary schools are much higher than those of general secondary schools. While general secondary schools are designed to prepare students to pursue their studies to higher education, and yet, their graduates go to work and their unemployment rate was lower than those of graduates from vocational secondary schools. 
The increase of unemployment rate of vocational secondary school graduates was caused by a not only oversupply of the workforce, but it was also caused by other factors such as economic growth, low quality of labor supply, capital vs labor-intensive, inappropriate location of building vocational secondary schools, inaccurate time of building vocational secondary schools, the stagnation of vocational institutions in developing skills for youth was further exacerbating unemployment, and vocational secondary schools do not teach well about entrepreneurship [6]. If the growth of the economy is low, the absorption of the labor force will be also low. The low quality of the workforce also causes an increase in the unemployment rate. The data released by The Ministry of Manpower of Indonesia concluded that every three job applicants only one was accepted due to a lack of skills required by the workplace. If industries tend to use capital intensive rather than laborintensive, then the industries will need less labor. If maritime vocational secondary schools are built in inappropriate locations i.e. maritime schools are built in the middle of the mainland and not in the rim, the graduates are not well informed with the jobs related to maritime. Inaccurate time of building vocational secondary schools also cause unemployment. For example, if electric car school graduates are needed in the next 15 years, but the schools are built now, the graduates will not be recruited now due to time lag. Stagnation of vocational institutions in developing skills for youth will also cause unemployment due to its obsolete skills taught. Unemployment is also caused by the fact that vocational secondary schools do not teach well on how to be an entrepreneur, but mostly only how to be an employee. Last but not least, vocational secondary schools do not teach well on how to make money, but only how to get money (salary). Therefore, it is proposed that a policy shift in vocational education be adopted (Table 2) [7].

Table 2. Policy Shift in Vocational Education

\begin{tabular}{ll}
\hline \multicolumn{1}{c}{ The Past } & The Future \\
\hline - Competency-based & - Capability based \\
system & system \\
- More focus on & - More focus on \\
preparing to be & preparing to be \\
employees & entrepreneurs \\
- Very limited money & - Broad money \\
literacy & literacy \\
- Current friendly & - Future friendly \\
- Preparing for jobs & - Preparing for future- \\
ready & ready \\
- What to think & - How to think \\
- Rigid and specific & - A flexible and broad \\
curriculum & curriculum \\
- Singled technology & - Fused technology \\
teaching & teaching \\
- Conventional learning & - Blended learning \\
- Limited learning & - Diverse learning \\
resources & resources \\
- Focus on teaching & - Focus on learning \\
- Individual intelligence & - Collective \\
- Voluntary roles of the & intelligence \\
world of work & - Legalized roles of \\
& the world of work \\
\hline
\end{tabular}

Commenting briefly on the desired end state of future vocational education, it is envisioned that vocational education in the future will prepare capability of graduates than mere competency, more focus on preparing entrepreneurs than employees to reduce the unemployment rate, more broad money literacy teaching, from current to future-friendly, from mere job-ready to future-ready, need to strengthen how to think and not merely what to think, flexible and broad-based curriculum, from single to fused technology teaching, from conventional to blended learning, from personal to collective intelligence, and roles of the world of work in vocational education must be legalized, not voluntary as at present.

To reduce the unemployment rate of vocational secondary school graduates, students must also be equipped with multiple 
intelligences to be skilled, flexible, agile and technologically literate graduates to confront volatile, uncertain, complex, and ambiguous future (Figure 3). Student multiple intelligences to be developed include such as intellectual, emotional, spiritual, collective, love, moral and ethical, aesthetical, kinesthetically, passionate, and curious quotients.

The $21^{\text {st }}$ century also requires skills such as learning and innovation skills, digital literacy skills and career and life skills and Pearson-Learning Curve Report elaborated more to include leadership, digital literacy, communication, emotional intelligence, entrepreneurship, global citizenship [8], problem-solving, and team working [9]. In the future, the types of multiple intelligences will not be confined to what is written here, but they will be growing in times of change. To reduce the unemployment rate of vocational secondary school graduates, it important that the growth of the economy must be accelerated to create demands of labor.

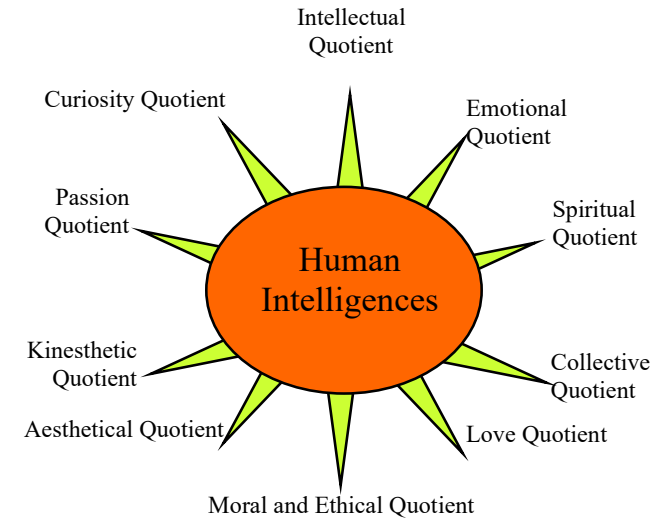

Figure 3. Multiple Intelligence Required by the $21^{\text {st }}$ Century

Table 3. Student Proportion of General Secondary School (GSS) and Vocational Secondary School (VSS) from 2016 to 2019

\begin{tabular}{|c|c|c|c|c|c|c|c|c|c|}
\hline \multirow{2}{*}{ No } & \multirow{2}{*}{ Province } & \multicolumn{2}{|c|}{2016} & \multicolumn{2}{|c|}{2017} & \multicolumn{2}{|c|}{2018} & \multicolumn{2}{|c|}{2019} \\
\hline & & GSS & VSS & GSS & VSS & GSS & VSS & GSS & VSS \\
\hline \multirow{2}{*}{1} & \multirow{2}{*}{ Jawa Barat } & 642,702 & 981,656 & 690,067 & $1,055,021$ & 704,565 & $1,075,411$ & 706,971 & $1,085,166$ \\
\hline & & $39.57 \%$ & $60.43 \%$ & $39.54 \%$ & $60.46 \%$ & $39.58 \%$ & $60.42 \%$ & $39.45 \%$ & $60.55 \%$ \\
\hline \multirow{2}{*}{2} & \multirow{2}{*}{ Jawa Timur } & 521,486 & 699,285 & 533,057 & 730,441 & 532,993 & 738,313 & 530,456 & 750,086 \\
\hline & & $42.72 \%$ & $57.28 \%$ & $42.19 \%$ & $57.81 \%$ & $41.92 \%$ & $58.08 \%$ & $41.42 \%$ & $58.58 \%$ \\
\hline \multirow{2}{*}{3} & \multirow{2}{*}{ Jawa Tengah } & 392,671 & 747,741 & 400,036 & 770,347 & 404,748 & 769,327 & 407,958 & 772,272 \\
\hline & & $34.43 \%$ & $65.57 \%$ & $34.18 \%$ & $65.82 \%$ & $34.47 \%$ & $65.53 \%$ & $34.57 \%$ & $65.43 \%$ \\
\hline \multirow{2}{*}{4} & \multirow{2}{*}{ Sumatera Utara } & 360,768 & 286,797 & 365,061 & 294,162 & 364,514 & 297,933 & 367,041 & 302,473 \\
\hline & & $55.71 \%$ & $44.29 \%$ & $55.38 \%$ & $44.62 \%$ & $55.03 \%$ & $44.97 \%$ & $54.82 \%$ & $45.18 \%$ \\
\hline \multirow{2}{*}{5} & \multirow{2}{*}{ Banten } & 179,037 & 237,467 & 181,787 & 249,485 & 183,862 & 252,032 & 189,232 & 253,186 \\
\hline & & $42.99 \%$ & $57.01 \%$ & $42.15 \%$ & $57.85 \%$ & $42.18 \%$ & $57.82 \%$ & $42.77 \%$ & $57.23 \%$ \\
\hline \multirow{2}{*}{6} & \multirow{2}{*}{ Sulawesi Selatan } & 231,402 & 126,103 & 232,593 & 129,422 & 228,784 & 130,042 & 225,957 & 131,344 \\
\hline & & $64.73 \%$ & $35.27 \%$ & $64.25 \%$ & $35.75 \%$ & $63.76 \%$ & $36.24 \%$ & $63.24 \%$ & $36.76 \%$ \\
\hline \multirow{2}{*}{7} & \multirow{2}{*}{ Sumatera Selatan } & 200,194 & 102,711 & 202,687 & 109,954 & 202,308 & 114,223 & 203,013 & 119,158 \\
\hline & & $66.09 \%$ & $33.91 \%$ & $64.83 \%$ & $35.17 \%$ & $63.91 \%$ & $36.09 \%$ & $63.01 \%$ & $36.99 \%$ \\
\hline \multirow{3}{*}{8} & \multirow{3}{*}{ D.K.I. Jakarta } & 166,860 & 211,351 & 170,637 & 217,153 & 166,278 & 222,740 & 163,274 & 222,154 \\
\hline & & $44.12 \%$ & $55.88 \%$ & $44.00 \%$ & $56.00 \%$ & $42.74 \%$ & $57.26 \%$ & $42.36 \%$ & $57.64 \%$ \\
\hline & & 148,745 & 129,554 & 151,374 & 136,932 & 150,358 & 140,791 & 150,653 & 145,280 \\
\hline 9 & Lampung & $53.45 \%$ & $46.55 \%$ & $52.50 \%$ & $47.50 \%$ & $51.64 \%$ & $48.36 \%$ & $50.91 \%$ & $49.09 \%$ \\
\hline \multirow{2}{*}{10} & Nusa Tenggara & 173,936 & 68,606 & 179,633 & 77,353 & 186,219 & 82,556 & 187,264 & 89,280 \\
\hline & Timur & $71.71 \%$ & $28.29 \%$ & $69.90 \%$ & $30.10 \%$ & $69.28 \%$ & $30.72 \%$ & $67.72 \%$ & $32.28 \%$ \\
\hline \multirow{2}{*}{11} & \multirow{2}{*}{ Riau } & 145,551 & 86,114 & 150,064 & 91,612 & 152,796 & 94,777 & 154,269 & 98,874 \\
\hline & & $62.83 \%$ & $37.17 \%$ & $62.09 \%$ & $37.91 \%$ & $61.72 \%$ & $38.28 \%$ & $60.94 \%$ & $39.06 \%$ \\
\hline \multirow{2}{*}{12} & \multirow{2}{*}{ Sumatera Barat } & 142,584 & 81,870 & 143,852 & 85,530 & 144,960 & 86,758 & 145,364 & 89,145 \\
\hline & & $63.52 \%$ & $36.48 \%$ & $62.71 \%$ & $37.29 \%$ & $62.56 \%$ & $37.44 \%$ & $61.99 \%$ & $38.01 \%$ \\
\hline
\end{tabular}




\begin{tabular}{|c|c|c|c|c|c|c|c|c|c|}
\hline \multirow{2}{*}{ No } & \multirow{2}{*}{ Province } & \multicolumn{2}{|c|}{2016} & \multicolumn{2}{|c|}{2017} & \multicolumn{2}{|c|}{2018} & \multicolumn{2}{|c|}{2019} \\
\hline & & GSS & VSS & GSS & VSS & GSS & VSS & GSS & VSS \\
\hline \multirow{2}{*}{13} & Kalimantan & 114,842 & 57,690 & 119,948 & 63,912 & 123,570 & 68,732 & 125,129 & 72,131 \\
\hline & Barat & $66.56 \%$ & $33.44 \%$ & $65.24 \%$ & $34.76 \%$ & $64.26 \%$ & $35.74 \%$ & $63.43 \%$ & $36.57 \%$ \\
\hline \multirow{2}{*}{14} & & 137,263 & 49,830 & 136,049 & 53,769 & 132,842 & 54,031 & 128,612 & 53,243 \\
\hline & Aceh & $73.37 \%$ & $26.63 \%$ & $71.67 \%$ & $28.33 \%$ & $71.09 \%$ & $28.91 \%$ & $70.72 \%$ & $29.28 \%$ \\
\hline \multirow{2}{*}{15} & Nusa Tenggara & 104,039 & 65,580 & 101,948 & 68,194 & 100,419 & 69,942 & 99,773 & 73,044 \\
\hline & Barat & $61.34 \%$ & $38.66 \%$ & $59.92 \%$ & $40.08 \%$ & $58.94 \%$ & $41.06 \%$ & $57.73 \%$ & $42.27 \%$ \\
\hline \multirow{2}{*}{16} & Bali & 84,646 & 90,716 & 86,352 & 96,063 & 87,751 & 98,233 & 89,207 & 98,916 \\
\hline & Ball & $48.27 \%$ & $51.73 \%$ & $47.34 \%$ & $52.66 \%$ & $47.18 \%$ & $52.82 \%$ & $47.42 \%$ & $52.58 \%$ \\
\hline \multirow{2}{*}{17} & Kalimantan & 68,797 & 71,770 & 71,937 & 73,951 & 73,884 & 74,883 & 74,628 & 76,752 \\
\hline & Timur & $48.94 \%$ & $51.06 \%$ & $49.31 \%$ & $50.69 \%$ & $49.66 \%$ & $50.34 \%$ & $49.30 \%$ & $50.70 \%$ \\
\hline \multirow{2}{*}{18} & Jambi & 74,249 & 45,988 & 60,835 & 30,722 & 76,229 & 50,050 & 76,214 & 51,699 \\
\hline & Jamb1 & $61.75 \%$ & $38.25 \%$ & $66.44 \%$ & $33.56 \%$ & $60.37 \%$ & $39.63 \%$ & $59.58 \%$ & $40.42 \%$ \\
\hline \multirow{2}{*}{19} & & 58,239 & 28,389 & 75,383 & 48,629 & 63,075 & 32,518 & 63,983 & 33,022 \\
\hline & Papua & $67.23 \%$ & $32.77 \%$ & $60.79 \%$ & $39.21 \%$ & $65.98 \%$ & $34.02 \%$ & $65.96 \%$ & $34.04 \%$ \\
\hline \multirow{2}{*}{20} & Kalimantan & 62,581 & 52,351 & 65,397 & 55,255 & 66,975 & 56,837 & 67,007 & 58,156 \\
\hline & Selatan & $54.45 \%$ & $45.55 \%$ & $54.20 \%$ & $45.80 \%$ & $54.09 \%$ & $45.91 \%$ & $53.54 \%$ & $46.46 \%$ \\
\hline \multirow{2}{*}{21} & & 68,811 & 41,841 & 70,656 & 44,677 & 73,163 & 44,486 & 55,896 & 87,833 \\
\hline & D.I. Y & $62.19 \%$ & $37.81 \%$ & $61.26 \%$ & $38.74 \%$ & $62.19 \%$ & $37.81 \%$ & $38.89 \%$ & $61.11 \%$ \\
\hline \multirow{2}{*}{22} & & 87,775 & 30,083 & 88,699 & 31,946 & 55,272 & 88,493 & 75,894 & 44,106 \\
\hline & Sulaw & $74.48 \%$ & $25.52 \%$ & $73.52 \%$ & $26.48 \%$ & $38.45 \%$ & $61.55 \%$ & $63.25 \%$ & $36.76 \%$ \\
\hline \multirow{2}{*}{23} & Sulawesi & 54,035 & 84,478 & 55,276 & 88,256 & 90,214 & 32,252 & 91,325 & 33,487 \\
\hline & Tenggara & $39.01 \%$ & $60.99 \%$ & $38.51 \%$ & $61.49 \%$ & $73.66 \%$ & $26.34 \%$ & $73.17 \%$ & $26.83 \%$ \\
\hline \multirow{2}{*}{24} & Kalimantan & 53,728 & 30,507 & 56,319 & 32,464 & 58,051 & 33,817 & 58,673 & 34,907 \\
\hline & Tengah & $63.78 \%$ & $36.22 \%$ & $63.43 \%$ & $36.57 \%$ & $63.19 \%$ & $36.81 \%$ & $62.70 \%$ & $37.30 \%$ \\
\hline \multirow[t]{2}{*}{25} & Sulawesi Utara & 56,195 & 48,920 & 59,089 & 49,593 & 61,094 & 49,728 & 61,970 & 49,383 \\
\hline & & $53.46 \%$ & $46.54 \%$ & $54.37 \%$ & $45.63 \%$ & $55.13 \%$ & $44.87 \%$ & $55.65 \%$ & $44.35 \%$ \\
\hline & & 68,292 & 20,002 & 68,914 & 21,089 & 69,338 & 21,068 & 69,529 & 21,410 \\
\hline 26 & Malu & $77.35 \%$ & $22.65 \%$ & $76.57 \%$ & $23.43 \%$ & $76.70 \%$ & $23.30 \%$ & $76.46 \%$ & $23.54 \%$ \\
\hline & & 47,713 & 25,701 & 41,732 & 29,304 & 43,674 & 29,664 & 46,280 & 31,464 \\
\hline 27 & K & $64.99 \%$ & $35.01 \%$ & $58.75 \%$ & $41.25 \%$ & $59.55 \%$ & $40.45 \%$ & $59.53 \%$ & $40.47 \%$ \\
\hline & & 38,409 & 27,147 & 48,217 & 27,237 & 47,080 & 27,999 & 48,914 & 29,362 \\
\hline 28 & B & $58.59 \%$ & $41.41 \%$ & $63.90 \%$ & $36.10 \%$ & $62.71 \%$ & $37.29 \%$ & $62.49 \%$ & $37.51 \%$ \\
\hline & Kepulauan & 26,905 & 25,657 & 28,661 & 26,021 & 27,365 & 24,082 & 28,209 & 25,082 \\
\hline 29 & Bangka Belitung & $51.19 \%$ & $48.81 \%$ & $52.41 \%$ & $47.59 \%$ & $53.19 \%$ & $46.81 \%$ & $52.93 \%$ & $47.07 \%$ \\
\hline 30 & Sulawesi Rarat & 36,872 & 16,016 & 38,029 & 16,683 & 29,768 & 26,419 & 29,769 & 27,234 \\
\hline 30 & Sulawes1 Barat & $69.72 \%$ & $30.28 \%$ & $69.51 \%$ & $30.49 \%$ & $52.98 \%$ & $47.02 \%$ & $52.22 \%$ & $47.78 \%$ \\
\hline 31 & & 24,165 & 22,765 & 25,919 & 23,536 & 39,015 & 16,679 & 39,217 & 17,572 \\
\hline 31 & Ma & $51.49 \%$ & $48.51 \%$ & $52.41 \%$ & $47.59 \%$ & $70.05 \%$ & $29.95 \%$ & $69.06 \%$ & $30.94 \%$ \\
\hline & & 26,041 & 19,339 & 26,392 & 12,649 & 26,530 & 13,501 & 26,917 & 14,286 \\
\hline 32 & Papua Barat & $57.38 \%$ & $42.62 \%$ & $67.60 \%$ & $32.40 \%$ & $66.27 \%$ & $33.73 \%$ & $65.33 \%$ & $34.67 \%$ \\
\hline & & 25,369 & 12,183 & 26,843 & 18,715 & 28,344 & 18,479 & 29,656 & 18,895 \\
\hline 33 & Gorontalo & $67.56 \%$ & $32.44 \%$ & $58.92 \%$ & $41.08 \%$ & $60.53 \%$ & $39.47 \%$ & $61.08 \%$ & $38.92 \%$ \\
\hline $34+2>3$ & Kalimantan & 15,763 & 8,444 & 16,004 & 8,946 & 16,479 & 8,848 & 16,868 & 9,443 \\
\hline 34 & Utara & $65.12 \%$ & $34.88 \%$ & $64.14 \%$ & $35.86 \%$ & $65.06 \%$ & $34.94 \%$ & $64.11 \%$ & $35.89 \%$ \\
\hline & Indonesian & 652 & - & 712 & - & 554 & 63 & 536 & 102 \\
\hline 35 & Schools abroad & $100.00 \%$ & $0.00 \%$ & $100.00 \%$ & $0.00 \%$ & $89.79 \%$ & $10.21 \%$ & $84.01 \%$ & $15.99 \%$ \\
\hline & & 67,827 & 39,968 & 69,953 & 40,312 & 71,910 & 40,892 & 73,980 & 42,727 \\
\hline & Total & $62.92 \%$ & $37.08 \%$ & $63.44 \%$ & $36.56 \%$ & $63.75 \%$ & $36.25 \%$ & $63.39 \%$ & $36.61 \%$ \\
\hline
\end{tabular}

Source: Data Analyzed from 34 Provinces and Validated with MOEC Data 
Table 4. Unemployment Rate of Population Aged 15 Based on Education Level 2016 to 2019 (in percentage)

\begin{tabular}{llrrrrrrrr}
\hline \multirow{2}{*}{ No } & \multirow{2}{*}{ Education Level } & \multicolumn{2}{c}{2016} & \multicolumn{2}{c}{2017} & \multicolumn{2}{c}{2018} & \multicolumn{2}{c}{2019} \\
& & February & August & February & August & February & August & February & August \\
\hline 1 & Primary School and Bellow & 3.44 & 2.88 & 3.54 & 2.62 & 2.67 & 2.43 & 2.65 & 2.41 \\
2 & Junior Secondary School & 5.76 & 5.71 & 5.36 & 5.54 & 5.18 & 4.80 & 5.04 & 4.75 \\
3 & General Secondary School & 6.95 & 8.72 & 7.03 & 8.29 & 7.19 & 7.95 & 6.78 & 7.92 \\
4 & Vocational Secondary School & 9.84 & 11.11 & 9.27 & 11.41 & 8.92 & 11.24 & 8.63 & 10.42 \\
5 & Diploma I/II/III & 7.22 & 6.04 & 6.35 & 6.04 & 7.92 & 6.02 & 6.89 & 5.99 \\
6 & University & 6.22 & 4.87 & 4.98 & 5.18 & 6.31 & 5.89 & 6.24 & 5.67 \\
& Total & 5.50 & 5.61 & 5.33 & 5.50 & 5.13 & 5.34 & 5.01 & 5.28 \\
\hline
\end{tabular}

Source: Data Analyzed from Indonesian Bureau of Statistics Center

Table 5. Student Proportion of General Secondary School (GSS) and Vocational Secondary School (VSS) in Six Provinces in Java Island 2016 to 2019

\begin{tabular}{llrrrrrrrr}
\hline \multirow{2}{*}{ No } & \multirow{2}{*}{ Province } & \multicolumn{2}{c}{2016} & \multicolumn{2}{c}{2017} & \multicolumn{2}{c}{2018} & \multicolumn{2}{c}{2019} \\
& & GSS & \multicolumn{1}{c}{ VSS } & \multicolumn{1}{c}{ GSS } & \multicolumn{1}{c}{ VSS } & \multicolumn{1}{c}{ GSS } & \multicolumn{1}{c}{ VSS } & \multicolumn{1}{c}{ GSS } & \multicolumn{1}{c}{ VSS } \\
\hline \multirow{2}{*}{1} & \multirow{2}{*}{ Banten } & 179,037 & 237,467 & 181,787 & 249,485 & 183,862 & 252,032 & 189,232 & 253,186 \\
& & $42.99 \%$ & $57.01 \%$ & $42.15 \%$ & $57.85 \%$ & $42.18 \%$ & $57.82 \%$ & $42.77 \%$ & $57.23 \%$ \\
\multirow{2}{*}{2} & D.K.I. & 166,860 & 211,351 & 170,637 & 217,153 & 166,278 & 222,740 & 163,274 & 222,154 \\
& Jakarta & $44.12 \%$ & $55.88 \%$ & $44.00 \%$ & $56.00 \%$ & $42.74 \%$ & $57.26 \%$ & $42.36 \%$ & $57.64 \%$ \\
\multirow{2}{*}{3} & Jawa Barat & 642,702 & 981,656 & 690,067 & $1,055,021$ & 704,565 & $1,075,411$ & 706,971 & $1,085,166$ \\
& $39.57 \%$ & $60.43 \%$ & $39.54 \%$ & $60.46 \%$ & $39.58 \%$ & $60.42 \%$ & $39.45 \%$ & $60.55 \%$ \\
\multirow{2}{*}{4} & D.I. & 68,811 & 41,841 & 70,656 & 44,677 & 73,163 & 44,486 & 55,896 & 87,833 \\
& Yogyakarta & $62.19 \%$ & $37.81 \%$ & $61.26 \%$ & $38.74 \%$ & $62.19 \%$ & $37.81 \%$ & $38.89 \%$ & $61.11 \%$ \\
\multirow{2}{*}{5} & Jawa Tengah & 392,671 & 747,741 & 400,036 & 770,347 & 404,748 & 769,327 & 407,958 & 772,272 \\
& $34.43 \%$ & $65.57 \%$ & $34.18 \%$ & $65.82 \%$ & $34.47 \%$ & $65.53 \%$ & $34.57 \%$ & $65.43 \%$ \\
\multirow{2}{*}{6} & Jawa Timur & 521,486 & 699,285 & 533,057 & 730,441 & 532,993 & 738,313 & 530,456 & 750,086 \\
& $42.72 \%$ & $57.28 \%$ & $42.19 \%$ & $57.81 \%$ & $41.92 \%$ & $58.08 \%$ & $41.42 \%$ & $58.58 \%$ \\
& Total & 303,565 & 486,556 & 341,040 & 511,187 & 344,268 & 483,640 & 342,297 & 528,449 \\
& $44.34 \%$ & $55.66 \%$ & $43.89 \%$ & $56.11 \%$ & $43.85 \%$ & $56.15 \%$ & $39.91 \%$ & $60.09 \%$ \\
\hline
\end{tabular}

Source: Data Analyzed from Offices of Education in Six Provinces in Java Island

Table 6. Unemployment Rate of Graduates from General Secondary School (GSS) and Vocational Secondary School (VSS) in Six Provinces in Java Island 2016 to 2019 (\%)

\begin{tabular}{lrrrrrrrr}
\hline \multicolumn{1}{c}{ Year } & \multicolumn{1}{c}{2016} & \multicolumn{2}{c}{2017} & \multicolumn{2}{c}{2018} & \multicolumn{2}{c}{2019} \\
\hline Province & GSS & VSS & GSS & VSS & GSS & VSS & GSS & VSS \\
Banten & 11.79 & 13.14 & 10.25 & 10.69 & 10.06 & 11.65 & 13.48 & 13.13 \\
DKI Jakarta & 8.03 & 12.13 & 7.97 & 10.86 & 8.09 & 9.65 & 7.44 & 9.56 \\
Jawa Barat & 11.40 & 16.51 & 10.03 & 16.80 & 9.78 & 16.97 & 10.89 & 15.53 \\
DIY & 2.81 & 4.07 & 4.39 & 4.38 & 2.87 & 4.91 & 3.94 & 3.87 \\
Jawa Tengah & 6.83 & 10.64 & 6.51 & 8.07 & 6.80 & 7.48 & 5.84 & 7.94 \\
Jawa Timur & 9.04 & 7.10 & 6.75 & 9.01 & 6.31 & 8.83 & 7.07 & 8.65 \\
\hline
\end{tabular}

Source: Data Analyzed from Bureau of Statistics Center in Six Provinces in Java Island

\section{CONCLUSION}

The national average proportion of general secondary school and vocational secondary school graduates was $62.92 \%: 37.08 \%$ in 2016 and 63.39\%:36.61\% in 2019. respectively. Specifically in Java Island. the percentage of vocational 
secondary students increase significantly from $44.34 \%: 55.66 \%$ in 2016 to 39.91\%:60.09\% in 2019. The national average unemployment rate of general secondary school and vocational secondary school graduates was $8.72 \%$ and $11.11 \% \%$. respectively in 2016 . and $7.92 \%$ and $10.42 \%$. respectively in 2019. Thus. the unemployment rate of vocational secondary school graduates was higher than their counterparts from general secondary school graduates.

The moratorium of expansion for vocational secondary schools must be taken into account for the time being. particularly in Java Island. Any additional vocational secondary schools must be based on a demand-driven system guided by labor market signals and be based on the result of policy analysis to rebalance the proportion of general secondary schools and vocational secondary schools in Java Island and outer Islands of Java. Realignment of vocational education policy. execution and practices are required so that there is an efficient school to work transition and thus contribute optimally to the formation of the workforce in Indonesia. The policy shift in the quality of vocational education and strong collaboration between vocational institutions and industry is also required to reduce the unemployment rate of vocational secondary graduates [7].

To strengthen link and match between vocational education as suppliers and the world of work as demander of labor. The labor market information system should be created and used to minimize the gap between supply and demand for labor. Graduates from vocational secondary schools must be skilled. flexible and technology-literate to meet the human resource demands of Indonesian economic development. Enterprise-based training. small and medium-sized enterprises should be taught extensively and intensively in vocational secondary schools [10]. At the same time. students of vocational secondary schools must learn about knowledge. skills. and attitudes required by global challenges [11]. Otherwise. they will be illiterate in the global era and consequently. they will be unemployed. To reduce the unemployment rate. it is also necessary to establish a National Board of Vocational Education consisting members of mostly from the world of work. represented by the chamber of commerce. labor organization. and other relevant government organizations such as the Ministry of Education and Culture. Ministry of Manpower. Ministry of Industry. and the Ministry of Trade. At the school and local district levels. career centers must be established to function in sharing labor market information. particularly job vacancy information to graduates [12]. Policy analysis is needed to provide accurate information to policymakers and practitioners to make accurate decisions about Indonesian vocational education development. Learning excellent practices from other countries is also needed. Therefore. cooperation with other countries having excellent vocational institutions such as Germany and Switzerland is urgently needed in terms of consultation in formulating a vision. mission. objectives. policy direction and policy dimensions. and policy implementation. such as dual system design and implementation.

\section{REFERENCES}

[1] Ministry of Education and Culture. Skills toward 2020 for Global Era. Ministry of Education and Culture. 1998.

[2] M. of M. Ministry of Education and Culture. A framework to Harmonize Education with the World of Work. Ministry of Education and Culture. Ministry of Manpower. 2010. 
[3] President Instruction Number 9. Year 2016 on Revitalization of Vocational Education to Improve Quality and Human Resource Competitiveness. the Republic of Indonesia. the Republic of Indonesia. 2016.

[4] P. Slamet. "The Contribution of Increasing the Number of Vocational Secondary Students to Economic Development in Indonesia." Cakrawala Pendidik. J. Ilm. Pendidik.. vol. XXXV. no. 3. 2016.

[5] S. P. Harto. Development of Vocational Secondary Schools for the Future. Jakarta: Directorate of Vocational Secondary School. Jakarta: Directorate of Vocational Secondary School. Ministry of Education and Culture. 2014.

[6] P. Slamet. "Pengembangan SMK Model untuk Masa Depan." Cakrawala Pendidik. J. Ilm. Pendidik. vol. XXXII. no. 1. 2013.

[7] P. Slamet. "Development of Vocational Education in the Era of Industrial Revolution 4.0.” 2019.
[8] J. Fallon. The Learning Curve: Education and Skills for Life. London. UK: Pearson Publishing Company. 2014.

[9] M. Samani. "Learning Strategy to Develop Critical Thinking. Creativity. and Problem Solving Skills for Vocational School Students." $J$. Pendidik. Teknol. dan Kejuru.. vol. 25. no. 1. 2019.

[10] Asian Development Bank. Good Practice in Technical and Vocational Education and Training. Manila. Philippines: Asian Development Bank. 2009

[11] H. Yusof and et al. "Knowledge. Skills. and Attitudes of Malaysian Student on Global Citizenship Education." Cakrawala Pendidik. J. Ilm. Pendidik. vol. 38. no. 3. 2019.

[12] L. Indana and Soenarto. "Vocational Career Center as the Bridge between Industry and Vocational High School Graduates." J. Pendidik. Teknol. dan Kejuru. vol. 25. no. 2. pp. 219-228. 2019. 